\title{
Pengelolaan Dana Desa untuk Pemberdayaan Masyarakat
}

\author{
Ujang Wahyu Utomo \\ Magister Ilmu Akuntansi, Universitas Lampung \\ Jl. Prof. Dr. Ir. Sumantri, Kec. Rajabasa, Kota Bandar Lampung, Lampung \\ E-mail: ujangwahyu0801@gmail.com
}

Received: Februari 2021; Accepted: Mei 2021; Published: Juni 2021

\begin{abstract}
Empowerment of village communities is a way for the welfare of village communities in various aspects, through good management of village funds, the opportunity to empower communities is very easy to do with the support of programs that are right on target and quality human resources. This study generally aims to determine the management of village funds for community empowerment. The research method used qualitative with a descriptive approach, the data collection technique was carried out with a research library, and there were two sources of data, namely primary and secondary. Data analysis used descriptive data analysis with three stages of data reduction, data display, and drawing conclusions. The results showed that, (1) the management of village fund allocation (ADD) which was sourced from central and regional government financial balance funds for the 2018 and 2019 fiscal years in Tri Mulya Jaya Village had been implemented but the results were not optimal. There is an imbalance in budget absorption, almost $35 \%$ of which is spent on village administration. (2) accountability for the realization of the APBDes has also been carried out transparently and accountably, and (3) residents appreciate the results of development and community empowerment that have been implemented by the village government.
\end{abstract}

Keyword: Management; Village Funds; Community Empowerment.

\begin{abstract}
Abstrak
Pemberdayaan masyarakat desa merupakan cara untuk mensejahterakan masyarakat desa dalam berbagai aspek, melalui pengelolaan dana desa yang baik, peluang pemberdayaan masyarakat sangat mudah dilakukan dengan dukungan program yang tepat sasaran dan sumber daya manusia yang berkualitas. Penelitian ini secara umum bertujuan untuk mengetahui pengelolaan dana desa untuk pemberdayaan masyarakat. Metode penelitian yang digunakan kualitatif dengan pendekatan deskriptif, teknik pengumpulan data dilakukan dengan penelitian kepustakaan, dan terdapat dua sumber data yaitu primer dan sekunder. Analisis data menggunakan analisis data deskriptif dengan tiga tahap reduksi data, penyajian data, dan penarikan kesimpulan. Hasil penelitian menunjukkan bahwa, (1) pengelolaan alokasi dana desa (ADD) yang bersumber dari dana perimbangan keuangan pemerintah pusat dan daerah tahun anggaran 2018 dan 2019 di Desa Tri Mulya Jaya sudah dilaksanakan namun hasilnya belum optimal. Terjadi ketimpangan penyerapan anggaran, hampir $35 \%$ di antaranya dihabiskan untuk administrasi desa. (2) pertanggungjawaban realisasi APBDes juga telah dilakukan secara transparan dan akuntabel, dan (3) warga mengapresiasi hasil pembangunan dan pemberdayaan masyarakat yang telah dilaksanakan oleh pemerintah desa.
\end{abstract}

Kata Kunci: Manajemen; Dana Desa; Pemberdayaan Masyarakat.

\section{PENDAHULUAN}

Bangsa Indonesia telah menetapkan beberapa landasan pokok negara dalam menyelenggarakan tugas pokok pemerintahan dan pembangunan nasional.Landasan tersebut adalah landasan idiil Pancasila, landasan konstitusional UUD 1945, landasan visional wawasan nusantara, dan landasan konseptual ketahanan nasional. Landasan inilah yang akan menjadi fondasi dan membentuk karakter sebuah bangsa (nation and character building). Sila kelima Pancasila, keadilan sosial bagi seluruh rakyat Indonesia bermakna menjaga keseimbangan-antara hak dan kewajiban untuk,saling menghormati orang lain. Pemerintah dari tingkat pusat hingga paling bawah, dalam hal ini adalah desa, bersama rakyat mempunyai kewajiban untuk

doi: https://doi.org/10.51544/jma.v6i1.1653

(C) 2021 Jurnal Mutiara Akuntansi . This is an open access article under the CC BY-SA license

Website: http://e-journal.sari-mutiara.ac.id/index.php/JMA/

http://e-journal.sari-mutiara.ac.id 
memanfaatkan, mengolah, dan membina sumber daya alam secara menyeluruh untuk mencapai tujuan pembangunan nasional, menciptakan masyarakat adil dan makmur, baik material maupun spiritual. Karena kewajiban dari agen pemberdayaan masyarakat dalam hal ini adalah aparat pemerintah sangat penting untuk menempatkan posisi yang sesuai dengan kondisi, situasi, potensi dan kebutuhan masyarakat, sehingga akan membentuk perilaku dan pola pikir yang membentuk masyarakat yang mempunyai kemampuan mengolah potensi yang dimiliki, baik dari sumber daya alam (SDA) maupun dari sumber daya manusia (SDM) yang sesuai dengan kebutuhan mereka (Hamid, 2016).

Amanat Undang-undang no 23 tahun 2014 tentang pemerintahan daerah yang merupakan perincian dari undang-undang no 33 tahun 2014 tentang perimbangan keuangan pusat dan daerah membawa angin segar atas kemandirian pemerintahan daerah atau otonomi daerah. Pemerintahan daerah terutama, provinsi maupun kabupaten/kota, memiliki wewenang untuk mengelola secara mandiri pemerintahan daerahnya secara lebih luwes, tentunya di bawah ramburambu undang-undang.Pemerintah daerah bertanggungjawab mewujudkan visi-misi program kerjanya, melakukan pemberdayaan masyarakat lokal, serta menumbuhkan setiap potensi sumber daya wilayahnya, mewujudkan iklim ekonomi konstruktif untuk kemaslahatan masyarakat. Pengembangan masyarakat merupakan sebuah proses yang memberikan banyak peruabahan pada berbagai aspek kehidupan masyarakat yang meliputi sosial, ekonomi, budaya, dan lingkungan (Sail \& Abu-samah, 2010). Pemerintah memiliki inisiatif yang cukup bagus dengan diwujudkannya dana desa sebagai langkah solutif mengurangi ketimpangan dalam tata laksana pembangunan nasional dan pembangunan daerah terutama pembangunan desa.

Peraturan Pemerintah (PP) No 72 Tahun 2005, pasal 64 ayat pertama dan kedua telah mengatur perencanaan pembangunan desa, bahwa pembangunan desa direncanakan secara berjangka meliputi Rencana Pembangunan Jangka Menengah Desa (RPJMDES) untuk jangka lima (5) tahun dan Rencana Kerja Pembangunan Desa (RKPD) dalam jangka satu (1) tahun, yang dibuat dan ditetapkan serta dijalankan oleh kepala desa dengan mengikuti peraturan daerah. Peraturan pemerintah merupakan bentuk perwujudan diberikannya alokasi dana desa, adanya aturan ini sangat jelas hak diberikan kepada desa untuk mendapatkan pembagian dari hasil pajak daerah dan retribusi daerah serta bagian dari dana perimbangan keuangan pusat dan daerah yang diterima oleh kabupaten. Sedangkan pelaksanaan alokasi dana desa dalam bentuk pembangunan fisik dan non fisik dengan memperhatikan indikator dari perkembangan desa, yakni: tingkat pendidikan, tingkat pendapatan, tingkat kesehatan. Kebijakan ini dinilai mampu memberikan pengaruh positif dengan pembangunan prasarana penunjang mobilitas masyarakat desa berupa jalan desa, namun masih belum merata dan belum maksimal menjangkau indikator lainnya. Kebijakan dalam pengalokasian dana desa pada APBN 2015-2017 telah menyebutkan bahwa pemerintah telah mengalokasikan dana desa dengan proporsi dan bobot formula $90 \%$ porsi yang dibagi rata (alokasi dasar), dan $10 \%$ porsi berdasarkan formula dengan poin pembagian jumlah penduduk desa $25 \%$, angka kemiskinan desa $35 \%$, luas wilayah desa $10 \%$, dan tingkat kesulitas geografis desa $30 \%$ (Kemenkeu, 2017).

Pemerintah selanjutnya mengupayakan perencanaan dana desa yang lebih baik. Sehingga dana desa diharapkan menjadi leading improvement yang bisa menyejajarkan perekonomian masyarakat di pedesaan dan mengurangi kesenjangan dengan masyarakat di perkotaan. Ketika dana desa dikelola dengan baik, diharapkan akan berimplikasi positif pada pencapaian kesejahteraan masyarakat dengan menonjolkan buah kreativitas masyarakat pedesaan. Hal ini juga merupakan eksistensi kemandirian desa itu sendiri, sebagaimana didefinisikan dalam Undang-undang No 6 tahun 2014, bahwa masyarakat hukum merupakan kesatuan yang memiliki 
batas wilayah yang berwenang dalam mengatur dan mengurus urusan pemerintahan, kepentingan masyarakat setempat berdasarkan prakarsa masyarakat, hak asal-usul, dan hak tradisional yang diakui, dan dihormati dalam sistem pemerintahan yang ada di Indonesia.

Peraturan menteri dalam negeri nomor 113 tahun 2014 tentang pengelolaan dana desa, dana desa merupakan dana yang bersumber dari Anggaran Pendapatan dan Belanja Negara yang diperuntukkan bagi desa, yang disalurkan melalui Anggaran Pendapatan dan Belanja Daerah Kabupaten/Kota digunakan untuk membiayai penyelenggaraan pemerintah daerah, pelaksanaan pembangunan, pembinaan kemasyarakatan dan pemberdayaan masyarakat. Pasal 1 ayat 6 menyebutkan pengelolaan keuangan desa merupakan keseluruhan kegiatan yang meliputi perencanaan, pelaksanaan, penatausahaan, pelaporan dan pertanggungjawaban keuangan desa (BPKP, 2015).

Para pengamat merumuskan di antara yang menjadi prioritas penggunaan dan pengelolaan dana desa diutamakan pada sektor kemandirian ekonomi masyarakat desa. Pertama, menumbuhkan ekonomi kreatif yang menjadi produk ciri khas desa tersebut.Kedua, pendirian serta pengembangan Badan Usaha Milik Desa (BUMDes) yang bisa menjadi soko kemandirian perekonomian masyarakat.Ketiga, pemaksimalan Koperasi Desa sebagai motor penggerak ekonomi masyarakat. Setelah sektor ekonomi berhasil dijalankan hingga mampu memberikan penghasilan mandiri bagi kas desa, maka pembangunan infrastruktur desa baru dijalankan, seperti: perbaikan dan pembangunan fasilitas umum desa seperti pengaspalan jalan, pembuatan lapangan bola/olahraga, saluran irigasi desa, maupun fasilitas gedung serbaguna dan lainnya.

Sehubungan dengan hal tersebut, dalam pelaksanaan pengelolaan alokasi dana desa peran serta masyarakat juga menjadi hal yang penting terutama dalam proses pengambilan keputusan dan pelaksanaan kegiatan yang menyangkut kebutuhan masyarakat desa. Selain itu, diperlukan juga adanya kerjasama yang baik antara aparatur desa dengan masyarakat dalam setiap tahapantahapan pengelolaan alokasi dana desa. Jika hal tersebut berjalan dengan baik makan besar kemungkinan masyarakat dapat lebih mengembangkan diri untuk mencapai kemajuan bersama seperti yang diharapkan dari program ini yaitu terciptanya masyarakat yang lebih berdaya. Selain melibatkan masyarakat, kegiatan pengelolaan alokasi dana desa juga turut melibatkan beberapa stakeholders seperti karang taruna, tim penggerak PKK, serta Badan Permusyawaratan Desa (BPD). Stakeholders tersebut diharapkan mampu untuk saling bekerja sama dalam pelaksanaan pengelolaan alokasi dana desa (Karimah, Saleh, \& Wanusmawatie, 2014). Berdasarkan pada studi pendahuluan diatas, maka penelitian ini bertujuan untuk mengetahui pengelolaan dana desa untuk pemberdayaan masyarakat yang ada pada kampung Tri Mulya Jaya, Banjar Agung, Tulang Bawang.

Penelitian ini hendak menjabarkan beberapa hal: Pertama, bagaimana pengelolaan alokasi dana desa dalam pemberdayaan masyarakat? Kedua, bagaimana peran para pejabat desa dalam pengelolaan alokasi dana desa? Ketiga, bagaimana pendapat warga soal pengelolaan dana desa apakah sudah sesuai dengan visi pemberdayaan masyarakat? Untuk menjawab beberapa rumusan tersebut, peneliti memfokuskan penelitian di satu titik yakni kantor Pemerintahan kampung Tri Mulya Jaya maupun portal pemerintahan kampung Tri Mulya (http://trimulyajaya.desa.id/) untuk menggali data-data yang obyektif dan layak dijadikan sebagai sumber data yang valid dan ilmiah. 


\section{TINJAUAN LITERATUR}

\section{Kampung Tri Mulya Jaya}

Tri Mulya Jaya merupakan sebuah desa yang letak administratifnya berada di Kecamatan Banjar Agung, Kabupaten Tulang Bawang, Provinsi Lampung.Kampung Tri Mulya Jaya awalnya merupakan sebuah dusun di wilayah kampung Tri Darma Wirajaya, yakni dusun RK 02 (Rukun Keluarga 02) dan dusun RK 05 (Rukun Keluarga 05).Karena terjadi pemekaran wilayah Kabupaten Tulang Bawang dibagi tiga dengan hadirnya Kabupaten Tulang Bawang Barat dan Kabupaten Mesuji, maka terjadi pemekaran pula di sektor kecamatan maupun desanya.Dari situ, lahirnya kampung Tri Mulya Jaya pada 3 September 2009.Secara pembagian administratif pula, kampung Tri Mulya jaya kemudian terbagi kedalam 4 RK. yaitu RK 01 (Rukun Keluarga 01) terdiri dari 4 RT (Empat Rukun Tetangga), RK 02 (Rukun Keluarga 02) terdiri dari 5 RT (Lima Rukun Tetangga), RK 03 (Rukun Keluarga 03) terdiri dari dari 5 RT (Lima Rukun Tetangga), RK 04 (Rukun Keluarga 04) terdiri dari 4 RT (Empat Rukun Tetangga).

Selanjutnya ditinjau secara geografis, wilayah kampung Tri Mulya Jaya seluas 751.50 Hektare atau $18.40 \mathrm{Km}$ berupa dataran rendah dengan ketinggian 17 meter di atas permukaan laut dengan akses kedalaman air sumur antara 8-18 meter. Ditinjau dari banyaknya sarana pendidikan dan keagamaan, Tri Mulya Jaya hanya memiliki 1 Gedung Sekolah Dasar, 3 Masjid, 6 Musholla, dan 1 Gereja Katolik.Secara demografis, penduduk kampung Tri Mulya Jaya sejumlah 1549 jiwa, terdiri dari beberapa suku adat istiadat yakni suku asli Lampung, Jawa, Sunda, Madura, Bali, dan Batak. Adapun agama atau kepercayaan yang dianut mayoritas penduduknya adalah Islam sebanyak 1.324 jiwa, Kristen Katolik sebanyak 147 jiwa, Kristen Protestan sebanyak 15 jiwa, dan Hindu sebanyak 8 jiwa. Adapun mayoritas pekerjaan penduduknya adalah petani dan berkebun tanaman karet.

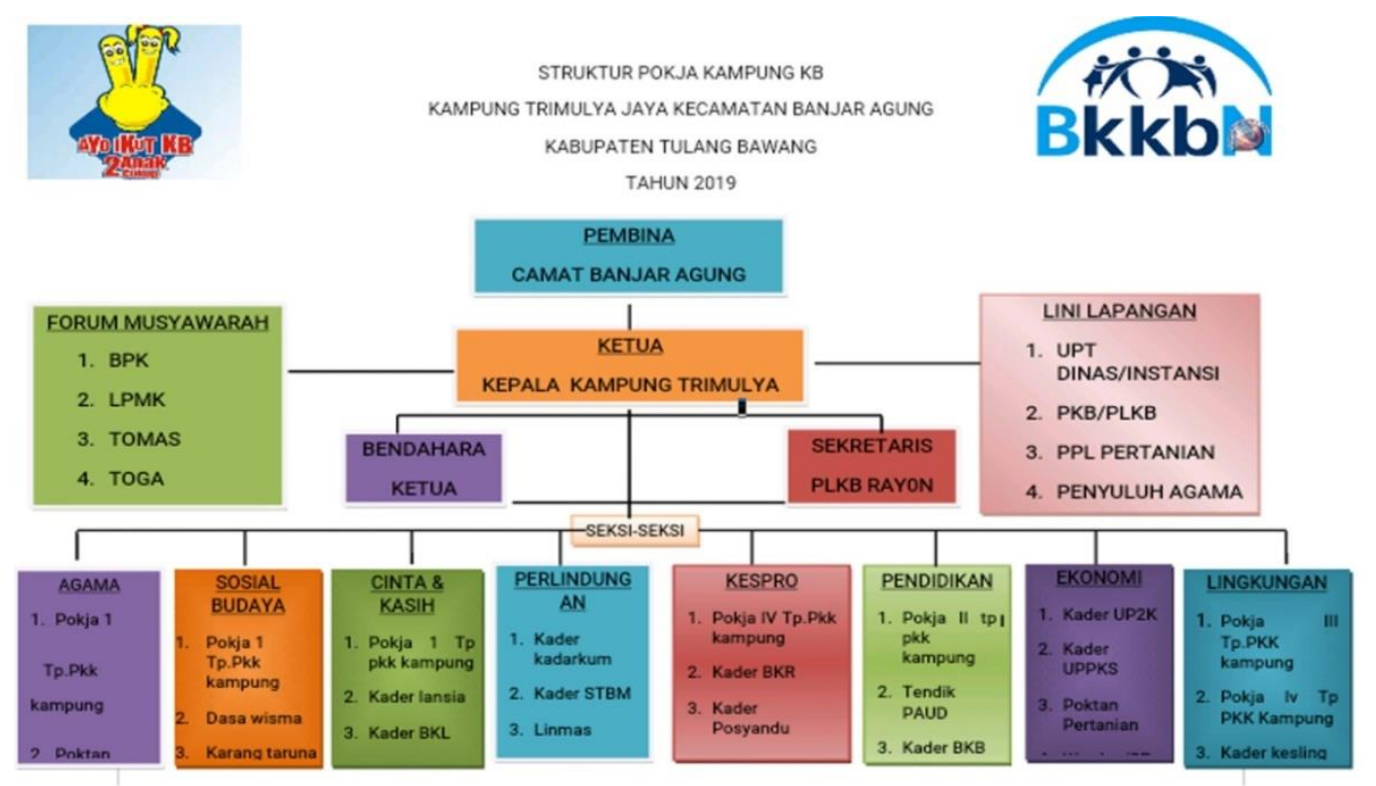

Gambar 1. Struktur Pokja Kampung Tri Mulya Jaya

Kepala desa dalam menajalankan pemerintahannya dibantu beberapa perangkat desa lainnya seperti sekretaris, bendahara, kepala dusun dan lainnya untuk menjalankan fungsi administrasi masyarakat sehari-hari.Selanjutnya untuk menyusun program kerja dan pemberdayaan masyarakat diadakan dalam musyawarah desa, yakni antara pemerintah desa bersama-sama dengan badan musyawarah desa yang terdiri dari wakil dari masyarakat desa yang membawa aspirasi untuk kemaslahatan dan pemberdayaan rakyat desa. 


\section{Administrasi dan Pengelolaan Keuangan}

Ada beberapa fungsi dari pengelolaan keuangan (1) tanggung jawab (accountability), suatu organisasi harus mempertanggungjawabkan keuangannya kepada lembaga atau orang yang berkepentingan yang sah, lembaga atau orang dan masyarakat umum. (2) mampu memenuhi kewajiban keuangan, di mana pengelolaan keuangan harus ditata dan dikelola sedemikian rupa sehingga mampu melunasi semua kewajiban atau ikatan keuangan baik jangka pendek, jangka panjang maupun pinjaman jangka panjang pada waktu yang telah ditentukan.(3) kejujuran, halhal yang menyangkut pengelolaan keuangan pada prinsipnya harus diserahkan kepada pegawai yang betul-betul jujur dan dapat dipercaya. (4) hasil guna (efectiveness) dan daya guna (efficiency), merupakan tata cara mengurus keuangan harus sedemikian rupa sehingga memungkinkan program dapat direncanakan dan dilaksanakan untuk mencapai tujuan dengan biaya yang serendah-rendahnya dalam waktu yang secepat-cepatnya. (5) pengendalian, di mana para aparat pengelola keuangan dan petugas pengawasan harus melakukan pengendalian agar semua tujuan tersebut dapat tercapai (Hasrina, 2015). Asas-asas pengelolaan keuangan desa tertuang dalam Permendagri Nomor 113 Tahun 2014 yaitu transparan, akuntabel, partisipatif serta dilakukandengan tertib dan disiplin anggaran.

\section{Alokasi Dana Desa}

Pengertian Keuangan Desa menurut Undnag-Undnag Desa adalah semua hak dan kewajiban desa yang dapat dinilai dengan uang serta segala sesuatu berupa uang dan barang yang berhubungan dengan pelaksanaan hak dan kewajiban Desa.Hak dan kewajiban tersebut menimbulkan pendapatan, belanja, pembiayaan yang perlu diatur dalam pengelolaan keuangan desa yang baik. Siklus pengelolaan keuangan desa meliputi perencanaan, pelaksanaan, penatausahaan, pelaporan, dan pertanggungjawaban, dengan periodisasi 1 (satu) tahun anggaran, terhitung mulai tanggal 1 Januari sampai dengan 31 Desember (BPKP, 2015).

Adanya Undang-undang Nomor 6Tahun 2014 Tentang Desa merupakan bagian dari dana perimbangan yangditerima kabupaten/kota paling sedikit $10 \%$ dalamanggaran pendapatan dan belanja daerah setelah dikurangi dana alokasikhusus. Dengan demikian alokasi dana desa selanjutnya yang disingkat ADD adalah dana perimbangan yang diterima kabupaten/kota dalam Anggaran Pendapatan dan Belanja Daerah kabupaten/kota setelah dikurangi.Dana Alokasi Khusus untuk digunakan secara proporsional sesuai dengan kebutuhan pembangunan dan pemberdayaan masyarakat desa.

\section{Pemberdayaan Masyarakat}

Pemberdayaan masyarakat desa merupakan salah satu upaya untuk meningkatkan kesejahteraan masyarakat, melalui beberapa kegiatan antara lain peningkatan prakarsa dan swadaya masyarakat, perbaikan lingkungan dan perumahan, pengembangan usaha ekonomi desa, pengembangan lembaga keuangan desa, serta kegiatan-kegiatan yang dapat meningkatkan kemampuan masyarakat dalam menaikkan hasil produksinya (Kehik, 2018).

Adapun pemberdayaan masyarakat menurut Undang-Undang Nomor 6 Tahun 2014 adalah upaya mengembangkan kemandirian dan kesejahteraan masyarakat dengan meningkatkan pengetahuan, sikap, keterampilan, perilaku, kemampuan, kesadaran, serta memanfaatkan sumber dayamelalui penetapan kebijakan, program, kegiatan, dan pendampingan yang sesuaidengan esensi masalah dan prioritas kebutuhan masyarakat desa.

\section{METODE PENELITIAN}


Penelitian ini menggunakan metode kualitatif dengan pendekatan yang dipilih adalah deskriptif. Penelitian yang bermaksud untuk memahami fenomena tentang apa yang dialami oleh subjek penelitian misalnya perilaku, persepsi, motivasi, tindakan dan lain-lain secaraholistik dan dengan cara deskripsi dalam bentuk kata-kata dan bahasa, pada suatu konteks khusus yang alamiah dan dengan memanfaatkan berbagai metode alamiah (Moleong, 2011). Sedangkan pendekatan deskriptif dipakai untuk meneliti status kelompok manusia, suatu subjek, suatu set kondisi, suatu sistem pemikiran atau pun kelas peristiwa pada masa sekarang. Tujuan dari penelitian deskriptif ini adalah membuat deskripsi, gambaran atau lukisan secara sistematis serta hubungan antar fenomena yang diselidiki (Nazir, 2011).

Penelitian ini menggunakan teknik pengumpulan data dengan library research, kegiatan penelitian dilakukan dengan cara mengumpulkan informasi dan data dengan bantuan berbagai macam material yang ada di perpustakaan seperti buku referensi, hasil penelitian sebelumnya yang sejenis, artikel, catatan, serta berbagai jurnal yang berkaitan dengan masalah yang ingin dipecahkan dan kegiatan dilakukan secara sistematis untuk mengumpulkan, mengolah, dan menyimpulkan data dengan menggunakan metode/teknik tertentu guna mencari jawaban atas permasalahan yang dihadapi (Sari \& Asmendri, 2020). Kemudian sumber data yang digunakan yaitu primer dan sekunder melalui wawancara sebagai data primer dan data sekunder diambil dari dokumen-dokumen yang mendukung penelitian ini, dan analisis data yang digunakan dalam peneltian ini adalah analisis deskriptif yang dibagi menjadi tiga yaitu reduksi data, display data, dan penarikan kesimpulan/ verifikasi (Sugiyono, 2015).

\section{HASIL DAN PEMBAHASAN}

Pengelolaan Alokasi Dana Desa

Alokasi dana desa tujuannya untuk meningkatkan kesejahteraan dan pemerataan pembangunan desa serta memaksimalkan pemberdayaan masyarakat desa baik di bidang ekonomi, pendidikan, dan kesehatan. Pengelolaan alokasi dana desa berkaitan langsung dengan penetapan Anggaran Pendapatan dan Belanja Desa (APBDes). Pengelolaan dana desa juga berkaitan dengan peran Badan Usaha Milik Desa (BUMDESA) dalam menggerakkan ekonomi desa. Sebagaimana diamanatkan dalam UU Desa, alokasi dana desa disesuaikan dengan jumlah penduduk, angka kemiskinan, luas wilayah serta tingkat kesulitan geografis.

Sebagaimana UU No 6 Tahun 2014 tentang Desa, perlu ditegaskan lagi bahwa tujuan Dana Desa adalah: (1) Meningkatkan pelayanan pubik di desa, (2) mengentaskan kemiskinan, (3) memajukan perekonomian desa, (4) mengatasi kesenjangan pembangunan antardesa, (5) memperkuat masyarakat desa sebagai subjek dari pembangunan. Berdasarkan keterbukaan masyarakat dalam pengelolaan Alokasi dana desa merupakan perencanaan yang baik, pelaksanaan nyata, penatausahaan yang sesuai dengan pelaksanaan, laporan berdasarkan pengeluaran dan pencatatan, tanggung jawab berdasarkan hasil laporan. Pembangunan bergantung dari masyarakat dengan istilah pemberdayaan dan pembangunan masyarakat untuk menjadi lebih baik dalam pengelolaan (Permatasari, Sopanah, \& Hasan, 2018). Pola dari kebijakan pemerintah yng ada dikabupaten yang semula hanya dominan dan sentralis melalui adanya metoe alokasi dana desa ini berubah menjdi partisipatif dan responsif yang dijalankan melalui asasa desentralisasi(Fisabilillah, Nisaq, \& Nurrahmawati, 2020).

Ada beberapa prinsip yang harus dipenuhi dalam setiap kegiatan yang bersumber dari alokasi dana desa. Pertama, mekanisme pertanggungjawaban secara administratif seperti perencanaan, pelaksanaan dan evaluasi secara terbuka dengan prinsip dari, oleh dan untuk masyarakat. Jika tidak demikian maka kepala desa akan berurusan dengan hukum dan peradilan. 
Kedua, alokasi dana desa dikelola secara terukur, hemat dan memiliki kebermanfaatan yang luas. Tiap-tiap program dan kegiatan yang bersumber dari alokasi dana desa diharapkan meningkatkan kualitas pemberdayaan masyarakat baik di bidang ekonomi, pendidikan maupun kesehatan. Di samping juga memajukan pembangunan desa, baik infrastruktur berupa jalan, listrik, sumur air, saluran irigasi dan lainnya yang berkaitan erat dengan pemenuhan kebutuhan dasar masyarakat.stabil. TSL et al (2013) Pemberdayaan masyarakat mengacu pada proses perubahan secara struktural masyarakat dengan pendekatan baru yang lebih baim agar masyarakat dapat kebutuhan ekonomi dan sosialnya (Fisabilillah et al., 2020).

\section{Pengelolaan Dana Desa Tahun Anggaran 2018}

Dalam catatan bendahara kampung Tri Mulya Jaya, didapatkan data bahwa jumlah anggaran Alokasi Dana Desa (ADD) dan Dana Desa (DD) pada tahun 2018 dalam satu tahun penuh, sebagaimana dicatat dalam APBKam sebesar Rp.1.299.796.925,-. Di mana dari dana tersebut akan dialokasikan di beberapa bidang yaitu:

Bidang I: Bidang Penyelenggaraan Pemerintah Desa (Sumber dana: DK, ADK, BUMDES dan Provinsi) anggarannya Rp563.804.142,-. Dana tersebut akan dialokasikan untuk beberapa kegiatan, yakni: (a) Penghasilan tetap Kepala Kampung dan perangkatnya (ADD: Rp109.740.000,-), (b) Insentif BPK dan anggota (ADD: Rp68.400.000,-), (c) Insentif rukun tetangga (RT) (ADD: Rp60.000.000,-); (d) Kegiatan operasional kantor kampung (DK, BUMDES dan Provinsi) anggarannya Rp128.965.124,-; (e) Kegiatan operasional badan permusyawaratan kampung (DK: Rp17.110.000,-); (f) Kegiatan operasional RT dan RK (ADD dan DD: Rp64.800.000,-), (g) Honor tim pelaksana teknis pengelolaan keuangan desa (PTPKB) (DD: Rp33.900.000,-); (h) Kegiatan penyusunan peraturan pemerintah kampung (DD: Rp3.250.000,-), (i) Kegiatan pembangunan sarana dan prasarana kantor kampung (ADD: Rp16.586.800,-), (j) Kegiatan pengelolaan teknologi informasi dan komunikasi kampung (TIK) (DD: Rp40.265.000,-), (k) Kegiatan operasional ambulan kampung (ADD: Rp15.787.200,-), dan (l) Kegiatan penunjang profil kampung (DD: Rp5.000.000,-).

Bidang II: Bidang Pembangunan desa (sumber dana: DD dan ADD) anggarannya Rp566.591.600,-. Dana desa tersebut dialokasikan untuk beberapa kegiatan, yakni: (a) Kegiatan pembangunan drainase batu belah 245 M /0,6×0,4 M lokasi RK 02 (DD: Rp85.765.200,-), (b) Kegiatan pembangunan gorong-gorong 4,5×0,6×0,6 M dua unit lokasi RK 01 dan RK 02 (ADD: Rp18.376.000,-), (c) Kegiatan pembangunan gorong-gorong 5×0,6×0,6 M dua unit lokasi RK 01 RK 03 (DD: Rp19.710.000,-), (d) Kegiatan pembangunan jalan kampung/onderlagh sepanjang 360×3 M lokasi di RK 01 (DD: Rp114.704.000,-), (e) Kegiatan pembangunan selokan 400 M/0,8×0,6 M lokasi RK 02, RK 03 dan RK 04 (DD: Rp11.056.000,-), (f) Kegiatan penerangan lingkungan pemukiman/pekarangan rumah (lampu ting 93 buah) (DD: Rp44.547.000,-), (g) Kegiatan pengadaan dan pembangunan air bersih bersekala kampung/sumur bor $40 \mathrm{M}$ Lokasi RK 03 (DD Rp38.568.000,-), (h) Kegiatan pengadaan mobil/kapal motor untuk ambulance kampung (ADD: Rp199.250.000,-), (i) Kegiatan pemeliharaan sarana dan prasarana pendidikan gedung PAUD lokasi RK 01 (DD: Rp14.521.400,-), (j) Kegiatan Pemeliharaan Sarana dan Prasarana infrastruktur Kampung (pemeliharaan PAMSIMAS lokasi RK 01) (DD Rp.6.120.000,), dan (k) Kegiatan pengadaan, pembangunan, pemanfaatan dan pemeliharaan sarana dan prasarana peribadatan keagamaan (kegiatan pengadaan Tenda Kematian) (Rp.13.974.000,-).

Bidang III: Bidang pembinaan masyarakat (sumber dana: DD) anggarannya sebesar Rp.83.680.000,- dialokasikan untuk beberapa kegiatan, yakni: (a) Kegiatan pembinaan ketentraman dan ketertiban di kampung LINMAS dianggarkan (DD: Rp16.100.000,-), (b) 
Kegiatan Pembinaan Karang Taruna (DD: Rp8.000.000,-), (c) Pembinaan Kesejahteraan Tenaga Honorer Pendidikan (DD: Rp5.400.000,-), (d) Pembinaan Kesenian Tradisional (DD: Rp8.000.000,-), (e) Pembinaan Ketentraman, Keamanan dan Ketertiban Masyarakat (DD: Rp2.000.000,-), (f) Kegiatan pembinaan lomba kampung/P3KSS dan GSI/kesrak PKK (DD: Rp10.000.000,-), (g) Pembinaan LPMK (DD Rp9.180.000,-), (h) Kegiatan Pembinaan PKK (DD: Rp19.200.000,-), dan (i) Kegiatan Pembinaan/Peningkatan Kader Posyandu (DD: Rp.5.800.000,-).

Bidang IV: Bidang Pemberdayaan Masyarakat (sumber dana: DD) anggarannya sebesar Rp.85.720.000,-, yang dialokasikan beberapa kegiatan, yakni: (a) Pemberian bantuan insentif guru PAUD/TK (DD: Rp19.200.000,-), (b) Pemberian bantuan insentif guru taman belajar keagamaan (DD: Rp27.000.000,-), (c) Bantuan bidang pemberdaya olahraga (DD: Rp4.900.000,), (d) Kegiatan pelatihan aparatur kampung (DD: Rp3.000.000,-), (e) Kegiatan bantuan insentif kader Posyandu dan kader kesehatan (DD: Rp6.000.000,-), (f) Kegiatan pemberdaya pekerja sosial masyarakat (DD: Rp5.500.000,-), (g) Kegiatan pengelolaan pemantauan pertumbuhan dan penyedia makanan sehat untuk peningkatan gizi bagi balita dan anak sekolah (DD: Rp3.120.000,-), (h) Kegiatan pengembangan sistem administrasi keuangan dan aset kampung berbasis data digital/DISKEUDES (DD: Rp3.000.000,-), (i) Kegiatan pengembangan unit pengaduan, bantuan hukum dan paralegal di kampung (DD: Rp3.000.000,-), (j) Kegiatan penyelenggaraan bantuan kepada warga miskin, warga disabilitas, perempuan, anak dan kelompok marginal (DD: Rp.5.000.000,-), (k) Kegiatan penyusunan profil kampung/data kampung (DD: Rp.3.000.000,-), dan (1) Pembuatan website kampung (DD: Rp.3.000.000,-).

\section{Pengelolaan Dana Desa Tahun Anggaran 2019}

Dalam catatan bendahara kampung Tri Mulya Jaya, didapatkan data bahwa jumlah anggaran Alokasi Dana Desa (ADD), Dana Desa (DD), BUMKam, Bantuan Kabupaten dan pendapatan lainnya pada tahun 2019 dalam satu tahun penuh, sebagaimana dicatat dalam APBKam sebesar Rp1.296.025.916,-

Bidang I: Penyelenggaraan pemerintahan desa dengan total anggaran Rp453.205.000,dialokasikan untuk beberapa kegiatan, yakni: (a) Siltap dan tunjangan kepala kampung dan perangkat desa Rp178.800.000,-; (b) Pembiayaan BPJS kepala kampung dan perangkat desa Rp5.616.000,-; (c) Operasional (ATK, HONOR PKPKD) sebesar Rp61.836.000,-; (d) Tunjangan PBD sebesar Rp68.400.000,- (e) Operasional PBD sebesar Rp7.000.000,-; (f) Siltap RT, sebesar Rp60.000.000,-; (g) Iuran APDESI Rp3.000.000, (h) Pembangunan Sarana (Aset tetap) Perkantoran Rp27.708.000,- 9. Pembiayaan tata praja pemerintah sebesar Rp40.845.000,--

Bidang II: Pelaksanaan pembangunan desa sebesar Rp96.124.916,- dialokasikan kedalam beberapa kegiatan, yakni: (a) Pembangunan sumur bor yang berada di RT 01. RW 04 dengan anggaran Rp25.695.850,- (b) Pembangunan jalan lapen, lokasi RT 01, RW 03 dengan Anggaran Rp309.695.350,- (c) Pembangunan Badan jalan RK 03. RW 04 dengan anggaran Rp74.689.000,(d) Pembangunan Gapura dengan lokasi RK 01 dengan anggaran Rp31.483.400. (e) Penyelengaraan PAUD, TPA (Honor) Rp 51.500.000,-. (f) Pengadaan Buku, Honor, Taman Baca sebesar Rp8.821.300,-. (g) Kegiatan Posyandu (KLS Bumil, Insentif), Bina Keluarga Balita (BKB) sebesar Rp20.003.616,- (h) Pemeliharaan jalan Rp3.000.000. (i) Pemeliharaan Gedung Balai Desa sebesar Rp3.500.000,-, (j) Lampu Ting Rp55.436.400. (10). Informasi Republik Desa (Poster Baliho) Rp7.200.000,-.

Bidang III: Pembinaan masyarakat desa dengan anggaran Rp150.196.000,- dengan alokasi beberapa kegiatan, yakni: (a) Pos keamanan desa sebesar Rp17.600.000,-; (b) Kesenian, 
kebudayaan tingkat desa sebesar Rp. 28.345.000,-; (c) Kepemudaan dan olahraga sebesar Rp3.450.000,-; (d) Honor LPMK sebesar Rp10.080.000,-; (e) Pembinaan PKK dan Honor sebesar Rp24.999.000,-; (f) Tunjangan (PSM) sebesar Rp5.723.000,-; (g) Operasional RT sebesar Rp60.000.000,-.

Bidang IV: Pemberdayaan masyarakat desa dengan anggaran sebesar Rp99.500.000,yang dialokasikan ke dalam beberapa kegiatan, yakni: (a) Pembuatan pakan fermentasi sebesar Rp 6.500.000,-; (b) Pengadaan bibit tanaman sebesar Rp3.500.000,-; (c) Peningkatan aparatur desa sebesar Rp3.500.000,- (d) Peningkatan kader Teknik sebesar Rp5.000.000,- (e) Kegiatan SISKUEDES sebesar Rp8.500.000,- (f) Kegiatan SIPADES sebesar Rp6.500.000,-; (g) Sosialisasi kampung layak anak sebesar Rp1.750.000,-; (h) Sosialisasi NARKOTIKA (NAPZA) sebesar Rp2.500.000,-; (i) Pengalihan dan pengelolaan dana BUMDES sebesar Rp1.750.000,-; (j) Kelompok usaha ekonomi produktif sebesar Rp60.000.000,-.

\section{Analsis}

Apabila ditelaah jumlah target kegiatan maupun program yang didanai dengan ADD maupun DD di atas bisa dilihat realisasi belanja APBDes Kampung Tri Mulya Jaya dilakukan secara maksimal 99\% danadesa yang diperoleh dan dikeluarkan dalam satu tahun anggaran tahun 2018 digunakan semuanya untuk membiayai setiap program kerja yang sudah disepakati dalam musyawarah desa. Artinya penyerapan anggaran sangat maksimal.Ada empat bidang yang menjadi fokus pembiayaan DD/ADD yakni bidang penyelenggaraan pemerintahan desa, bidang pembangunan desa, bidang pembinaan masyarakat, bidang pemberdayaan masyarakat.Semuanya sudah dijalankan sesuai programyang ditetapkan seperti di atas.Sementara realisasi belanja APBDes tahun anggaran 2019 kurang maksimal, terutama dari bidang pembangunan hanya terserap sekitar $30 \%$ saja.

Alokasi Dana Desa untuk bidang pembangunan desa baik tahun anggaran 2018 cukup dimaksimalkan yakni besarannya 35\% dari total APBDes. Namun yang menjadi catatan adalah beban pembiayaan penyelenggaraan pemerintahan desa cukup besar hampir $40 \%$ dari total APBDes, artinya dengan besaran dana untuk pembiayaan gaji dan honor kepala kampung serta perangkat desa lainnya berdampak pada minimnya dana untuk penyelenggaraan bidang pemberdayaan masyarakat dan pembinaan masyarakat. Kalau dilihat dari rincian laporan pengeluaran ADD/DD tahun angaran 2018, dapat dilihat ada cost pengeluaran yang jomplang antara bidang penyelengaraan pemerintahan desa (tahun anggaran 2018 : Rp453.205.000,- ), bidang pembinaan masyarakat desa (tahun anggaran 2018 : Rp83.680.000,-) sementara bidang pemberdayaan masyarakat desa (tahun anggaran 2018 : Rp.85.720.000,-).

Lain halnya dengan tahun anggaran 2019, realisasi anggaran sebagian besarnya terserap untuk pembiayaan penyelenggaraan pemerintah desa. Bahkan ada yang timpang antara besaran penyelenggaraan pemerintahan (tahun anggaran 2019 : Rp453.205.000,-) dengan tiga bidang lainnya, pembangunan desa (tahun anggaran 2019 : Rp96.124.916,-), pembinaan masyarakat desa (tahun anggaran 2019 : Rp150.196.000,- ), serta pemberdayaan masyarakat ( tahun anggaran 2019 : Rp99.500.000,-). Penulis melihat realisasi APBDes kurang maksimal untuk program- dan kegiatan pemberdayaan masyarakat.

Dilihat dari aspek pelaksanaan serta pertanggungjawaban pengelolaan dana desa Kampung Tri Mulya Jaya, penulis melihat bahwa pengelolaan ADD Kampung Tri Mulya Jaya sudah dijalankan dengan asas transparan dan akuntabel. Antara hasil fisik pelaksanaan kegiatan sudah sesuai dengan apa yang sebelumnya sudah direncanakan dalam musyawarah desa. Kendati demikian, pengelolaan masih kurang partisipatif, artinya masih ada beberapa perangkat terutama 
kepala seksi bidang pembangunan desa yang kinerjanya kurang maksimal sehingga penyerapan pembangunan terutama pada tahun anggaran 2019.

\section{Peran Pejabat Desa dalam Pengelolaan Alokasi Dana Desa}

Peran utama dalam pengelolaan dana desa di kampung Tri Mulya Jaya tentunya masih dipegang oleh kepemimpinan kepala desa, Ujang Wahyu Utomo (2017-2022) baik dalam perencanaan program maupun pengeksekusi setiap kegiatan yang berjalan. Kesemuanya di bawah pantauan dari kepala kampung Tri Mulya Jaya. Dalam pelaksanaan teknis administratif kepala desa dibantu oleh perangkat desa lainnya seperti: (1) sekretaris kampung Tri Mulya Jaya, yang bertindak sebagai koordinator administratif sekaligus pelaksanaan pengelolaan rencana strategis APBDes. (2) bendahara kampung Tri Mulya Jaya yang bertugas sebagai koordinator dalam bidang pengelolaan keuangan serta BUMDES kampung Tri Mulya Jaya. (3) kepala Seksi di berbagai bidangnya, yang bertugas sebagai pelaksana teknis setiap kegiatan dan bertanggungjawab menyukseskan setiap program yang sudah dianggarkan dalam APBDes di bidangnya masing-masing. Namun daam amatan penulis kinerjanya masih kurang maksimal terutama di bidang pembangunan.Sehingga kepala desa pun turut bertindak sebagai kepala proyek yang langsung memantau jalannya kegiatan pembangunan. Pemberdayaan masyarakat dirancang sejalan dengan prinsip berkelanjutan jika program dirancang dan dilaksanakan dengan memperhatikan keberlanjutan dari segi ekonomi dan sosial (Hulu, Harahap, \& Nasution, 2018).

Kegiatan pengelolaan keuangan desa dapat terlaksana dengan baik, tentunya harus didukung dengan sistem dan prosedur keuangan yang memadai. Oleh karena itu, pemerintah desa harus memiliki struktur organisasi pengelolaan keuangan, uraian tugas, diagram alir, dan kriteria yang menjadi acuan dalam kegiatan pengelolaan keuangan desa. Tahap perencanaan pemerintah desa harus melibatkan warga desa yang diwakili oleh Badan Permusyawaratan Desa (BPD) agar bekerja (Wahyuningsih \& Kiswanto, 2016)

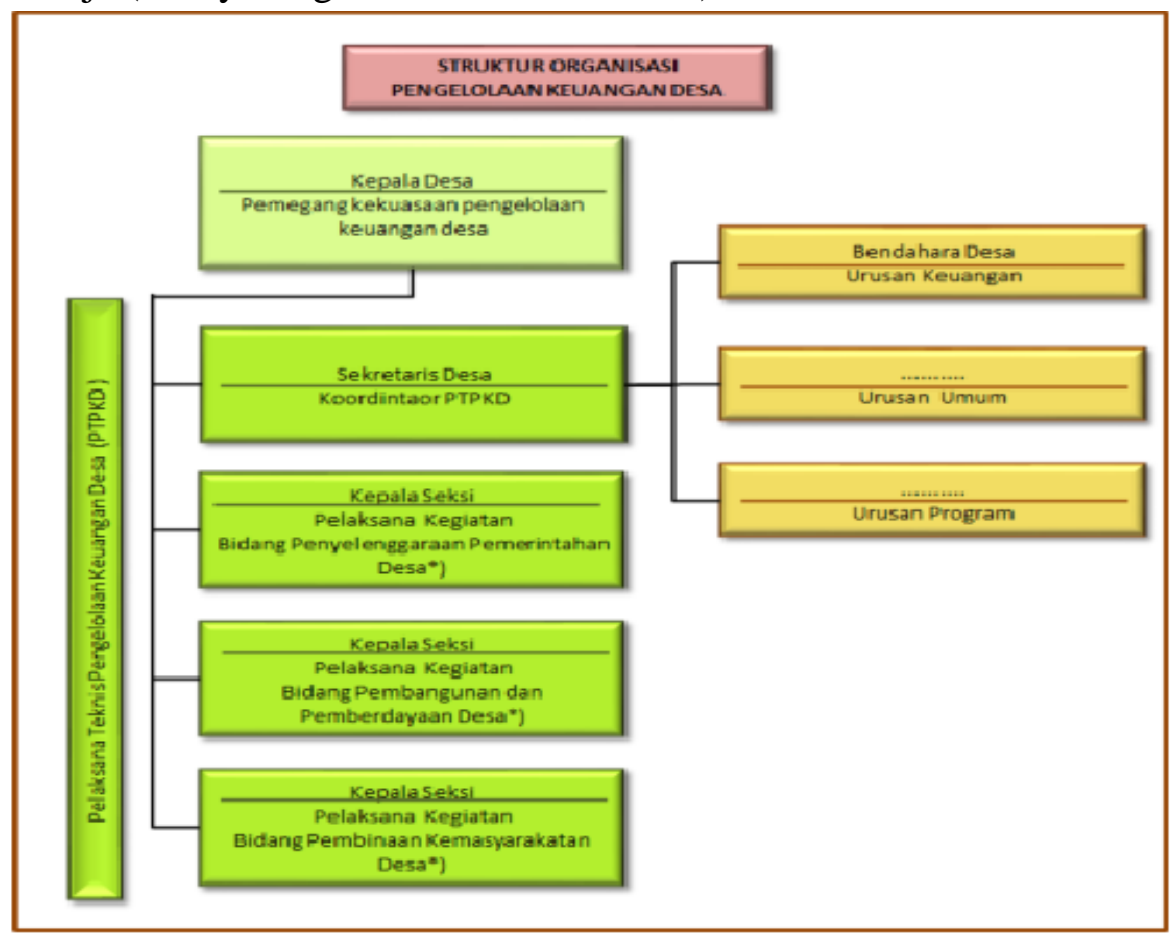

Gambar 2: Struktur Organisasi Pengelolaan Keungan Kampung 


\section{Pendapat Warga atas Hasil Pengelolaan Dana Desa untuk Pemberdayaan Masyarakat}

Evaluasi Alokasi Dana Desa dibutuhkan untuk memastikan bahwa di setiap tahapan pengelolaan Dana Desa tidak terjadi tindak pidana korupsi, penyelewengan maupun penyimpangan.Meskipun sejatinya pengunaan Dana Desa merupakan hak Pemerintah Desa sesuai dengan kewenangan dan prioritas kebutuhan masyarakat desa setempat dengan mengedepankan prinsip keadilan.Namun demikian, dalam rangka mengawal dan memastikan capaian sasaran pembangunan desa, harus ada langkah-langkah evaluasi di dalam teknis pelaksanaan APBDes.

Hasil pemberdayaan dari Alokasi Dana Desa ini, penulis paparkan hasil wawancara singkat dengan alah satu warga kampung Tri Mulya Jaya, bernama Miftahuddin, panggilan Udin (40 tahun) ia menjabarkan bahwa sejak adanya ADD maupun DD, telah terjadi pembangunan desa yang signifikan. Pembangunan infrastruktur maupun kegiatan pemberdayaan masyarakat yang disusun pemerintahan kampung Tri Mulya Jaya sangat bermanfaat dan membantu kemajuan serta kemandirian perekonomian masyarakat.

Pertanyaan: Bagaimana pendapat bapak soal hasil Alokasi Dana Desa dalam pemberdayaan masyarakat di kampung Tri Mulya Jaya?

Jawaban: "Alhamdulillah. Kami ucapkan terimakasih atas kinerja pemerintahan kampung Tri Mulya jaya di bawah kepemimpinan bapak Ujang Wahyu Utomo memang sepantasnya patut diacungi jempol, sudah jelas terlihat banyak perkembangan dan perubahan baik dari sektor pembangunan maupun sektor lainnya. Sekali lagi saya sangat berterimakasih dengan adanya pembangunan-pembangunan yang bersumber dari dana Desa (DD) karena ini sangat membantu kami, terutama dalam segi perekonomian dan kemajuan desa kami, dengan adanya pembangunan pembukaan jalan, lapen, sumur bor, dan gapura, sehingga dengan adanya pembangunan-pembangunan ini bisa di nikmati oleh masyarakat khususnya kampung Tri Mulya jaya, ucap Udin, saat di wawancara di lokasi kegiatan," tegas Eko.

Sementara itu, Sekertaris kampung Tri Mulya Jaya, Sulis (30) juga mengapresiasi program dan kegiatan di desanya yang sudah sangat baik dieksekusi untuk pemberdayaan masyarakat setempat.Ia juga berharap dari pemerintah daerah melalui dinas terkait, bisa memberikan tambahan bantuan agar pembangunan-pembangunan di kampung Tri Mulya Jaya yang boleh dikatakan lebih tertinggal dari desa lainnya di Provinsi Lampung. Ia bersyukur meskipun dalam keterbatasan dana desa ada beberapa infrastruktur telah dibangun dengan megah dan kokoh.

Pertanyaan: Bagaimana pendapat ibu untuk ADD apakah sudah berhasil optimal dalam pemberdayaan masyarakat kampung Tri Mulya Jaya?

Jawaban: "Kalau ditanya soal berhasil atau tidak itu bisa sama-sama dirasakan oleh masyarakat ya..Dahulu infrastruktur jalan di sini sangat terbatas, dan kini sudah mulai tersambung jalan dari desa ke setiap RK. Tentunya ada plus minus pengalokasian DD, di satu sisi infrastruktur dibutuhkan, namun di sisi lain pembiayaan administrasi untuk pemerintahan desa sendiri juga besar. Harapannya kedepan tentunya ADD nilainya akan lebih besar, BUMDES juga bisa maksimal kinerjanya untuk meningkatkan DD, supaya anggaran tahun depan lebih banyak untuk pembangunan infrastruktur untuk menunjang 
kegiatan ekonomi masyarakat. Supaya dengan adanya pembangunan-pembangunan dan fasilitas desa yang bersumber dari DD dan ADD yang ada di kampung Tri Mulya Jaya ini bisa dinikmati oleh masyarakat agar kampung Tri Mulya Jaya ini kedepannya bia mandiri dan berkemajuan dalam segala bidang," tegas Sulis.

\section{KESIMPULAN}

Pertama, pengelolaan Alokasi dana desa (ADD) yang bersumber dari dana perimbangan keuangan pemerintah pusat dan daerah tahun anggaran 2018 dan 2019 di Kampung Tri Mulya Jaya sudah dilaksanakan namun hasilnya kurang maksimal. Ada ketimpangan penyerapan anggaran yang realisasinya hampir 35\% dihabiskan untuk penyelenggaraan pemerintahan desa.

Kedua, peran utama dalam pengelolaan dana desa di Kampung Tri Mulya Jaya tentunya masih dipegang oleh kepemimpinan kepala desa, Ujang Wahyu Utomo (2017-2022) baik dalam perencanaan program maupun pengeksekusi setiap kegiatan yang berjalan. Pertanggungjawaban realisasi APBDes pun sudah dilakukan dengan transparan dan akuntabel. Sementara perangkat lainnya sudah bekerja dengan cukup baik meskipun ada beberapa kepala teknis yang kurang maksimal kinerjanya sehingga penyerapan pembangunan desa pun terganggu.

Ketiga, warga mengapresiasi hasil pembangunan dan pemberdayaan masyarakat yang sudah dilaksanakan oleh pemerintahan kampung Tri Mulya Jaya.Mereka berharap pembangunan infrastruktur lebih dioptimalkan lagi karena berdampak langsung pada mobilitas perekonomian masyarakat.

\section{DAFTAR PUSTAKA}

BPKP. (2015). Petunjuk pelaksanaan bimbingan dan konsultasi pengelolaan keuangan desa. In Badan Pengawasan Keuangan dan Pembangunan (BPKP). Jakarta: Badan Pengawasan Keuangan dan Pembangunan.

Fisabilillah, Febby Febriantika Noer, Nisaq, Azizatun Rochmatul, \& Nurrahmawati, Siti. (2020). Efektivitas Pengelolaan Dana Desa dalam Pemberdayaan Masyarakat. 8(1), 208-215.

Hamid, Hendrawati. (2016). Manajemen Pemberdayaan Masyarakat. In Tuty Seciaty Razak (Ed.), J+Plus Unesa (1st ed., Vol. 5). Makassar: De La Macca.

Hasrina, Yunita. (2015). ANALISIS PENGELOLAAN KEUANGAN RURAL INFRASTUCTURE SUPPORT PROGRAM NASIONAL PEMBERDAYAAN MASYARAKAT (RIS-PNPM) DI ORGANISASI MASYARAKAT SETEMPAT (OMS) KECAMATAN TUAH NEGERI KABUPATEN MUSI RAWAS. Jurnal Manajemen Dan Bisnis Sriwijaya, 13(4), 476-486.

Hulu, Yamulia, Harahap, R. Hamdani, \& Nasution, Muhammad Arif. (2018). Jurnal Pendidikan Ilmu-Ilmu Sosial Pengelolaan Dana Desa dalam Pemberdayaan Masyarakat. Jurnal Pendidikan Ilmu-Ilmu Sosial, 10(1), 146-154.

Karimah, Faizatul, Saleh, Choirul, \& Wanusmawatie, Ike. (2014). Pengelolaan alokasi dana desa dalam pemberdayaan masyarakat (Studi pada Desa Deket Kulon Kecamatan Deket Kabupaten Lamongan). Jurnal Administrasi Publik, 2(4), 597-602.

Kehik, Bernardus Seran. (2018). Pelaksanaan Program Pemberdayaan Masyarakat Desa di Bidang Ekonomi Kemasyarakatan ( Studi Kasus di Desa Naiola Kecamatan Bikomi Selatan Kabupaten Timor Tengah Utara ). Jurnal Agribisnis Lahan Kering, 3(2502), 4-6. 
Kemenkeu. (2017). Buku Pintar Dana Desa: Dana Desa Untuk Kesejahteraan Masyarakat. In Kementerian Keuangan Revublik Indonesiaublik Indonesia. Retrieved from https://www.kemenkeu.go.id/media/6749/buku-pintar-dana-desa.pdf

Permatasari, Elysabeth, Sopanah, \& Hasan, Khojanah. (2018). Pengelolaan alokasi dana desa dalam meningkatkan pembangunan dan pemberdayaan masyarakat desa. Conference on Innovation and Application of Science and Technology (CIASTECH 2018), (September), 186-194. Malang: Universitas Widyagama Malang.

Sail, Rahim M., \& Abu-samah, Asnarulkhadi. (2010). Community Development through Community Capacity Building: A Social Science Perspective. Journal of American Science, 6(2), 62-69.

Sari, Milya, \& Asmendri. (2020). Penelitian Kepustakaan (Library Research) dalam Penelitian Pendidikan IPA. Natural Science: Jurnal Penelitian Bidang IPA Dan Pendidikan IPA, 6(1), 41-53. Retrieved from https://ejournal.uinib.ac.id/jurnal/index.php/naturalscience/ article/view/1555/1159

Wahyuningsih, Putri, \& Kiswanto. (2016). Factors Affecting The Accountability of Village Financial Management. Accounting Analysis Journal, 5(3), 139-146. 